\title{
REVIEW
}

\section{Number-Based Approach to Insulin Taxonomy}

Sanjay Kalra · Yashdeep Gupta

To view enhanced content go to www.diabetestherapy-open.com

Received: July 14, 2015 / Published online: September 9, 2015

(C) The Author(s) 2015. This article is published with open access at Springerlink.com

\section{ABSTRACT}

This article describes a number-based system for the classification of insulin regimes. It utilizes a patient-centered variable (number of injections per day) and pharmacokinetic/dynamic characteristics to craft a taxonomic system that is able to incorporate all available insulin preparations and coformulations. This framework of systematics is robust enough to include various molecules that have been recently developed. It serves to enhance understanding of the subject, and facilitates the practical or clinical usage of theoretical knowledge. We propose that number-based insulin taxonomic models should be used in clinical guidelines and recommendations rather than restricting ourselves to pharmaceutical-based classifications. PubMed articles including both review articles and

S. Kalra $(\bowtie)$

Department of Endocrinology, Bharti Hospital, Karnal, India

e-mail: brideknl@gmail.com

Y. Gupta

Department of Endocrinology, All India Institute of Medical Sciences, New Delhi, India clinical trials published since the year 1990 were searched, to gather evidence and information on the various types of insulins available, and how they can be used, based on the number or frequency of injections prescribed per day.

Keywords: Aspart; Basal insulin; BiAsp; Coformulation of insulin; Degludec; Glargine; Glulisine; Insulin; Intensive insulin; Lispro; LisproMix; IDegAsp; IDegLira; LixiLan; Premixed insulin; U300

\section{INTRODUCTION}

The term "taxonomy" is used to describe the classification of various things, so the term "drug taxonomy" refers to the science of listing and describing drugs, according to various properties, in a manner which allows easy comprehension and understanding of their usage.

Traditionally, only pharmaceutical properties (e.g., chemical structure and pharmacodynamic and pharmacokinetic characteristics) have been used to separate 
drugs into various groups. Increasingly, however, the end user (i.e., the patient's or community's perspective) is considered when studying pharmacology $[1,2]$. In the present work, we provide a balanced, syncretic approach to insulin taxonomy, using both patient-centered and pharmacokinetic aspects, to craft a number-based classification of insulin regimes.

This article is based on previously conducted studies and does not involve any new studies of human or animal subjects performed by any of the authors.

\section{CURRENT INSULIN TAXONOMY}

Endocrinology and diabetology textbooks provide comprehensive coverage of various insulin preparations and then utilize these to discuss different insulin regimes. The current American Diabetes Association (ADA)/European Association for Study of Diabetes (EASD) 2015 guidelines use the terms "basal," "basal plus," "premixed," "split-mix," and "intensive" to describe insulin regimes [3]. Other terms used for regimes involving 3 or more injections per day are "multiple" and "intensified" insulin therapy. This drug-centered or pharmaceutical-based terminology served diabetology practitioners adequately in the past; the corresponding taxonomic methodology was able to incorporate the limited insulin preparations available, which included both traditional and modern insulins. This pharmaceutical classification of insulin regimes is not, however, syntaxic with the current emphasis on a patient-centered approach. It must be reemphasized here that it is patient-centeredness which forms the basis for recent advances in drug development and improvements in treatment guidelines.

\section{PATIENT-CENTERED INSULIN TAXONOMY}

Most patients of diabetes do not appreciate the pharmacodynamic or kinetic nuances of insulin preparations. What is more relevant to the person requiring insulin is the number of injections to be taken per day, the timing of administration, and the flexibility with which these timings can be adjusted. Based upon these factors, it is important to craft a fresh synopsis of insulin regimes, using the number of injections per day as the framework for systematic study. At the same time, such a classification system must address the nature of insulin preparations, whether basal, premixed, or prandial.

Modern clinical trials are available which support the use of premixed insulin in once-daily and thrice-daily dosages, as opposed to the traditional twice-daily regime. The basal insulins detemir and glargine often need to be prescribed twice daily in order to achieve adequate glycemic control. Innovative regimes utilizing combinations of rapid-acting and premixed/coformulated insulins with varying frequencies of administration have also been documented. These factors also provide important reasons to revisit current classifications of insulin preparations.

\section{NUMBER-BASED CLASSIFICATION OF INSULIN REGIMES}

While a number-based terminology has already been proposed [4], it is inadequate to cover the current range of insulin preparations and the large number of regimens that they are used in. With the newer insulin analogues available, a modern, number-based classification is required. Table 1 lists the various insulin 
Table 1 Insulin preparations that are currently on the market, along with the prescription patterns for them

\begin{tabular}{|c|c|c|c|}
\hline Frequency of injection & Name of regimen & $\begin{array}{l}\text { Insulin preparations } \\
\text { used }\end{array}$ & Timing of administration \\
\hline \multirow[t]{6}{*}{1 (once a day) } & Basal & $\begin{array}{l}\text { NPH, IDet, IGlar, I } \\
\text { glar U300 }\end{array}$ & $\begin{array}{l}\text { At bedtime or the same time every } \\
\text { day }\end{array}$ \\
\hline & Basal & IDeg & At any time of the day \\
\hline & Premixed & BIAsp, LisproMix & With major meal \\
\hline & Coformulation & IDegAsp & With major meal \\
\hline & Basal + GLP1RA & IDeg + liraglutide & At any time of the day \\
\hline & & IGlar + lixisenatide & \\
\hline \multirow[t]{4}{*}{2 (twice a day) } & Basal & NPH, IDet, IGlar & At bedtime and in the morning \\
\hline & Premixed & BHI, BIAsp, LisproMix & With major meals ${ }^{a}$ \\
\hline & Coformulation & IDeg Asp & With major meals ${ }^{\mathrm{b}}$ \\
\hline & Basal plus & Basal + prandial & At bedtime + with major meal \\
\hline \multirow[t]{4}{*}{3 (thrice a day) } & Prandial & $\begin{array}{l}\text { Regular, aspart, lispro, } \\
\text { glulisine }\end{array}$ & With meals \\
\hline & Bolus-bolus-premixed & Prandial + premixed & With meals \\
\hline & Premixed-bolus-premixed & Prandial + premixed & With meals \\
\hline & Bolus-bolus-coformulation & Aspart + IDegAsp & With meals \\
\hline 4 or 5 (four or five times a day) & Basal-bolus & $\begin{array}{l}\text { Any combination of } \\
\text { basal and bolus }\end{array}$ & $\begin{array}{l}\text { With meals [3], and at bedtime or } \\
\text { twice daily }\end{array}$ \\
\hline $\begin{array}{l}\text { CSI (continuous insulin } \\
\text { infusion pump) }\end{array}$ & \multicolumn{3}{|c|}{ Alternative to multiple injection } \\
\hline
\end{tabular}

regimes and preparations as well as the frequency and timing of administration for each. All regimes enumerated in this table are backed by randomized controlled trials, as shown in Table 2.

Newer ultralong-acting basal insulins and coformulations of ultralong-acting insulin analogues with either rapid-acting insulin analogues, or with GLP-1RA (glucagon-like peptide-1 receptor agonists), have recently been introduced. While these newer preparations are a combination of two preparations, they definitely do not fit into the earlier category of premixed insulins. They differ from previous molecules in their kinetic properties as well as their versatility. Other molecules, such as PEGylated lispro, are also in advanced stages of development, and will soon be available for clinical use.

Once-daily injections include all basal, premixed, and coformulation insulins. If necessary, these can be used in a twice-daily regime. Basal insulins were initially thought to be used once a day. As NPH, glargine, and 


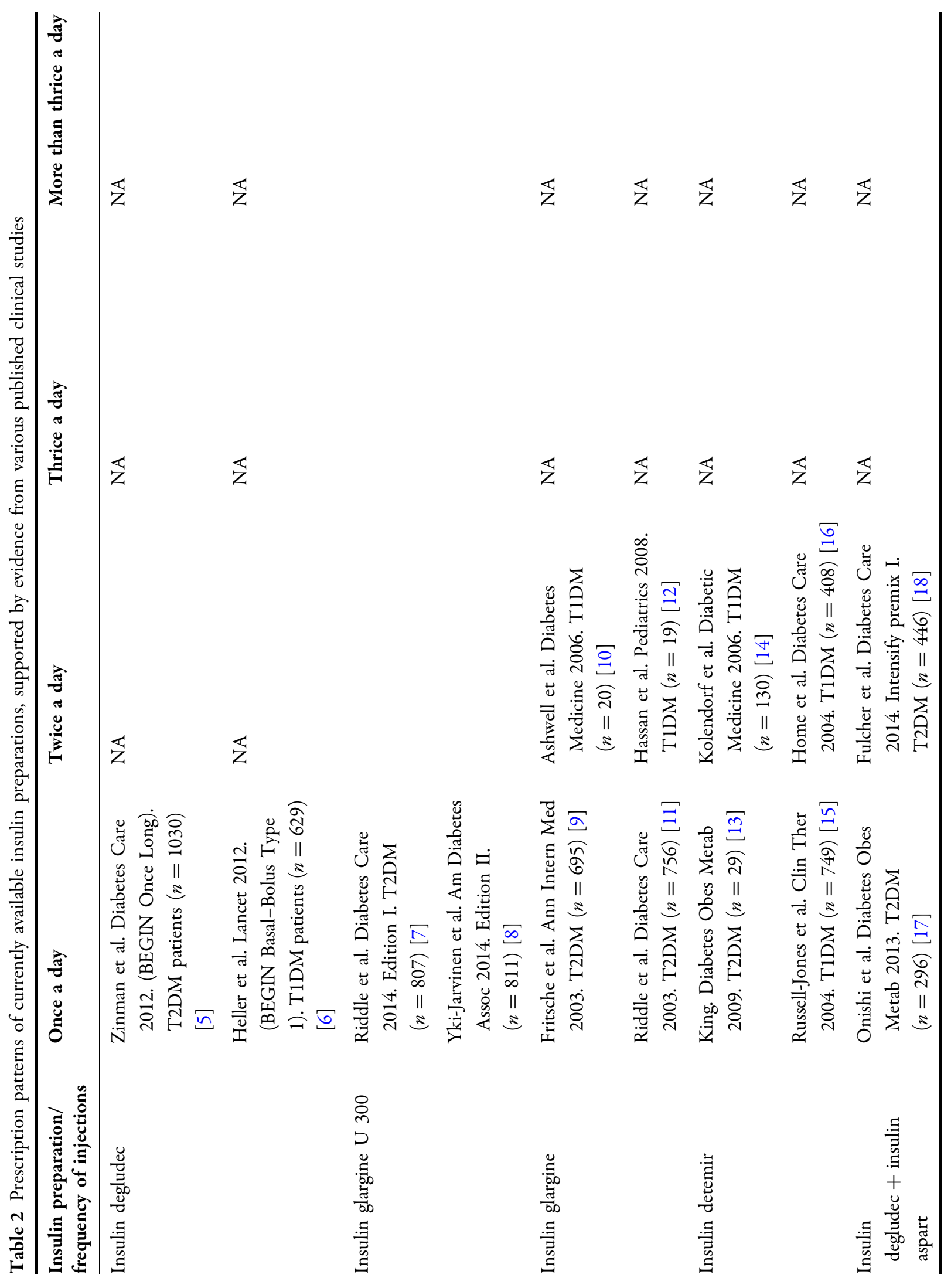




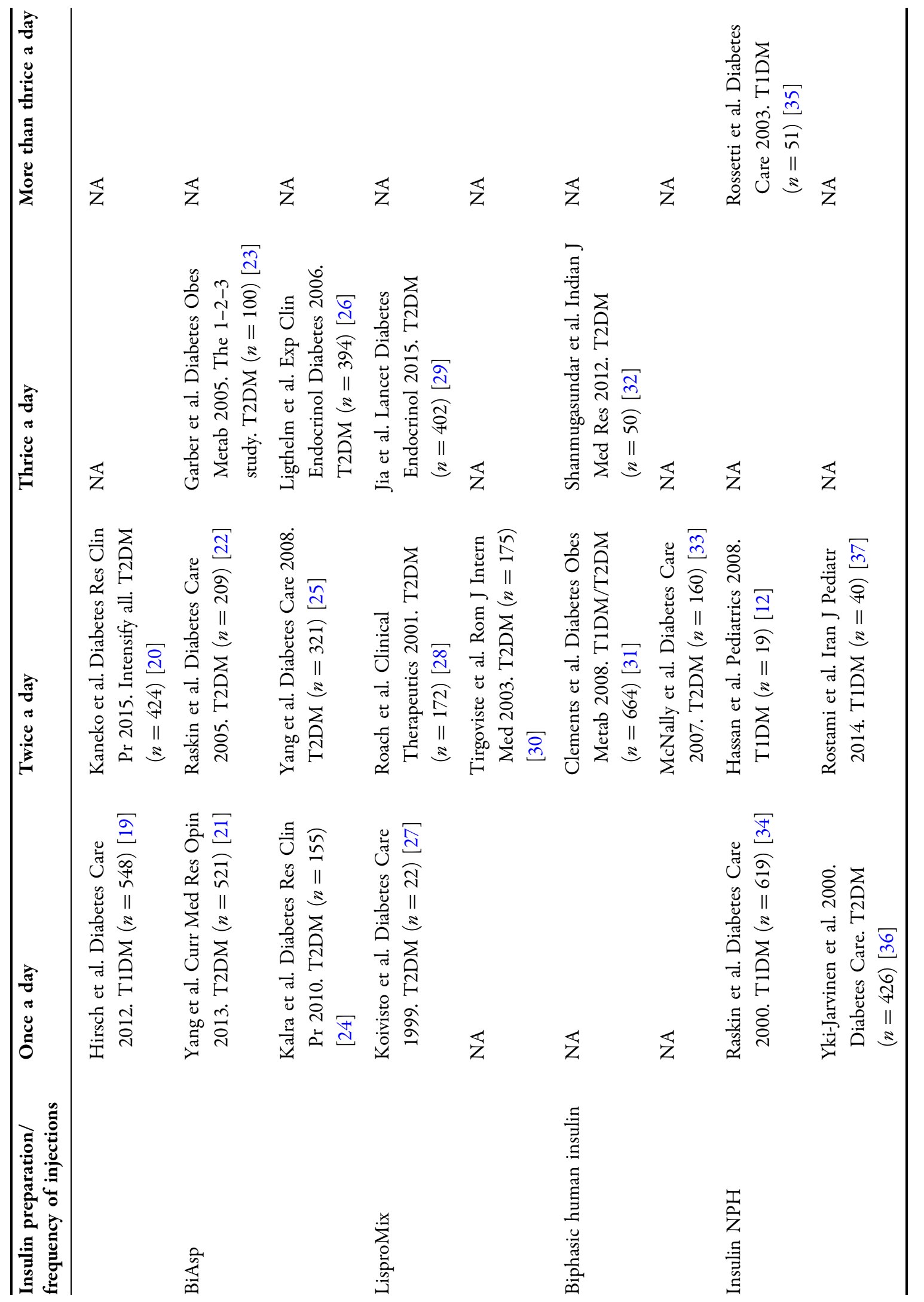




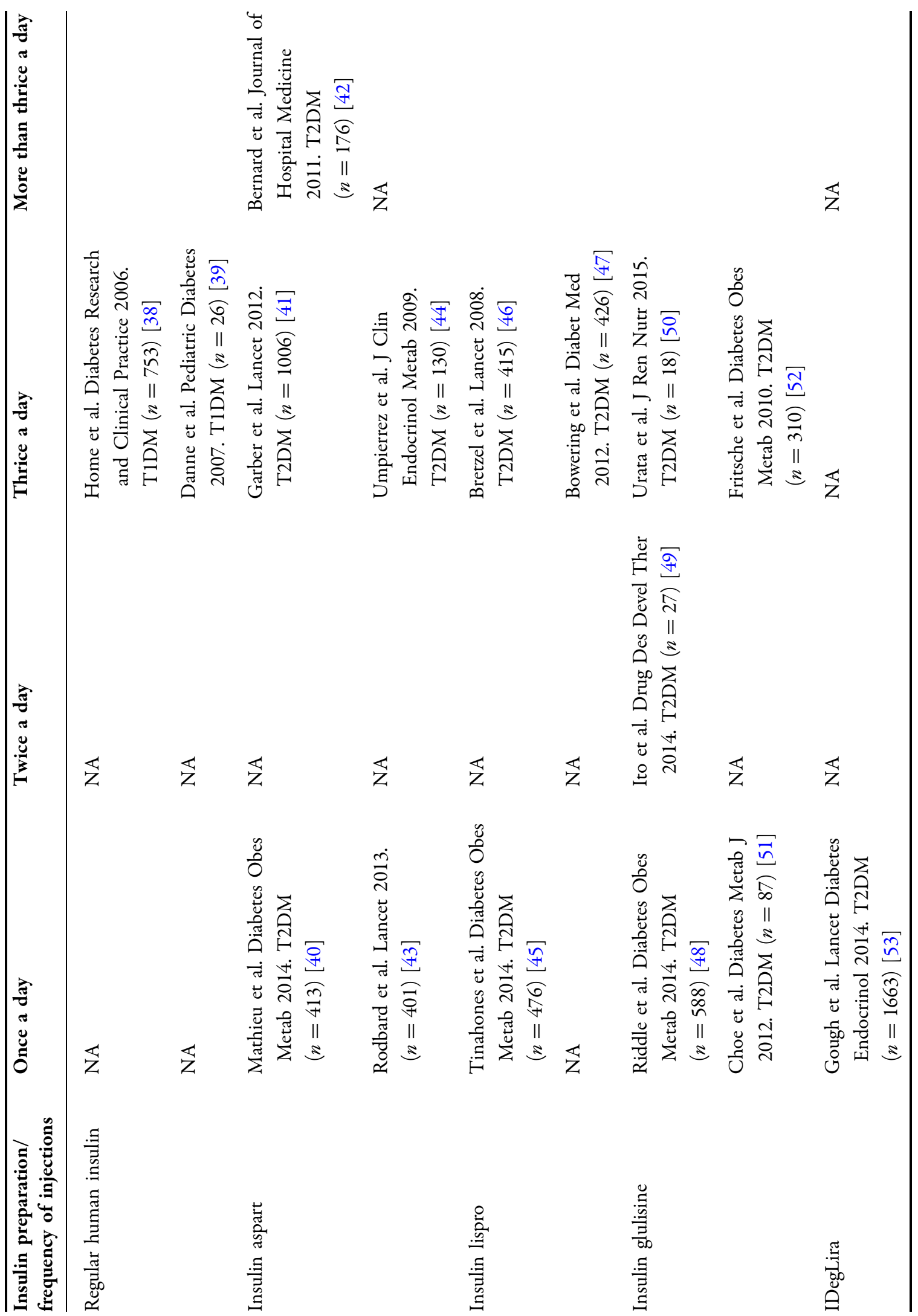




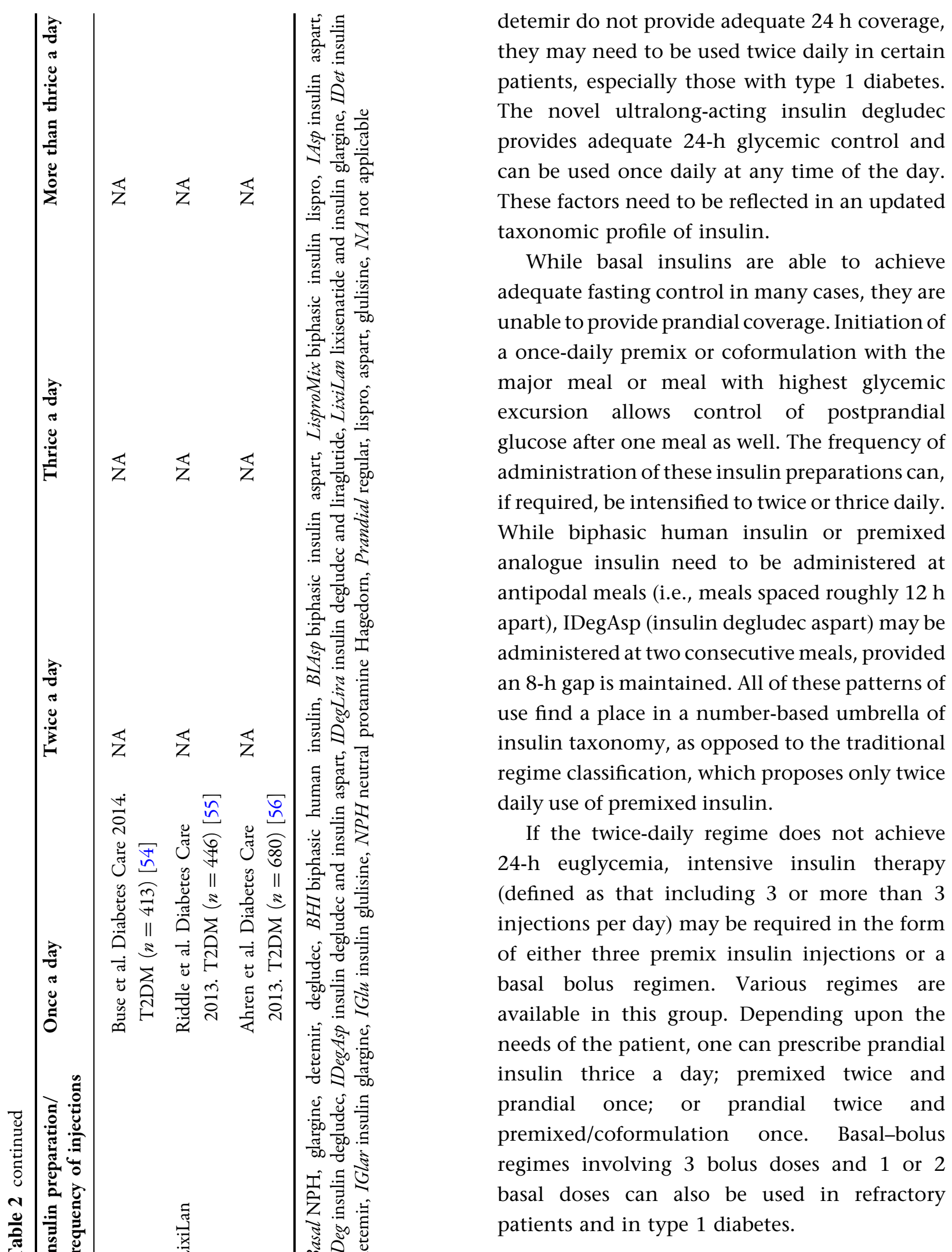




\section{CONCLUSION}

The number-based taxonomy is able to include all of these regimes as subclasses (Table 1), based upon published randomized controlled trials (Table 2). This arrangement makes it much simpler for the student to understand the subject of insulin pharmacotherapeutics. It helps the practitioner to appreciate the versatility of insulin and the many ways in which this life-saving molecule can be used. This system also allows the physician to choose the appropriate regime for a particular patient while following person-centeredness in letter and spirit. At the same time, choice of regime should take biomedical factors such as severity of hyperglycemia, risk of hypoglycemia, and diabesity indices into account.

Such a codification would promote appropriate choice of therapy based upon the individual's glucophenotype, motivation level, and psychosocial limitations, ease of use, and acceptance of insulin, by sensitizing the diabetes care professional to the patient's needs. It also facilitates the gradual intensification of therapy with the same insulin.

We therefore propose that future guidelines and recommendations utilize this person-centered arrangement of insulin regimes, rather than straitjacketing preparations according to traditional criteria.

\section{ACKNOWLEDGMENTS}

No funding or sponsorship was received for this study or publication of this article. All named authors meet the International Committee of Medical Journal Editors (ICMJE) criteria for authorship for this manuscript, take responsibility for the integrity of the work as a whole, and have given final approval for the version to be published.

Conflict of interest. S. Kalra has received speaker/advisory fees from Eli Lilly, Novo Nordisk, and Sanofi-Aventis in the recent past. Y. Gupta declares no conflict of interest.

Compliance with ethics guidelines. This article is based on previously conducted studies and does not involve any new studies of human or animal subjects performed by any of the authors.

Open Access. This article is distributed under the terms of the Creative Commons Attribution-NonCommercial 4.0 International License (http://creativecommons.org/licenses/ by-nc/4.0/), which permits any noncommercial use, distribution, and reproduction in any medium, provided you give appropriate credit to the original author(s) and the source, provide a link to the Creative Commons license, and indicate if changes were made.

\section{REFERENCES}

1. Maiti R, Alloza JL. Social pharmacology: expanding horizons. Indian J Pharmacol. 2014;46:246-50.

2. Kalra S, Gupta Y. Social pharmacology and diabetes. Indian J Pharmacol. 2014;46:564.

3. Inzucchi $S$, Bergenstal $R$, Buse J, Diamant $M$, Ferrannini E, Nauck $M$, et al. Management of hyperglycemia in type 2 diabetes, 2015: a patient centered approach update to a position statement of the American Diabetes Association and the European Association for the Study of Diabetes. Diabetes Care. 2015;38:140-9.

4. Kalra B, Kalra S. Choosing an insulin analogue regime. Internet J Geriatr Gerontol. 2009;5(2). https://ispub. com/IJGG/5/2/11006. Accessed 7 Sep 2015.

5. Zinman B, Philis-Tsimikas A, Cariou B, Handelsman Y, Rodbard HW, Johansen T, et al. Insulin degludec versus insulin glargine in insulin-naive patients 
with type 2 diabetes: a 1-year, randomized, treat-to-target trial (BEGIN Once Long). Diabetes Care. 2012;35(12):2464-71.

6. Heller S, Buse J, Fisher M, Garg S, Marre M, Merker L, et al. Insulin degludec, an ultra-long acting basal insulin, versus insulin glargine in basal-bolus treatment with mealtime insulin aspart in type 1 diabetes (BEGIN Basal-Bolus Type 1): a phase 3, randomised, open-label, treat-to-target non-inferiority trial. Lancet. 2012;379(9825):1489-97.

7. Riddle MC, Bolli GB, Ziemen M, et al. New insulin glargine 300 units/ml versus glargine 100 units $/ \mathrm{ml}$ in people with type 2 diabetes using basal and mealtime insulin: glucose control and hypoglycemia in a 6-month randomized controlled trial (EDITION 1). Diabetes Care. 2014;37(10):2755-62

8. Yki-Jarvinen H, Bergenstal RM, Bolli GB, et al. Less nocturnal hypoglycemia and weight gain with new insulin glargine $300 \mathrm{U} / \mathrm{ml}$ compared with 100 $\mathrm{U} / \mathrm{ml}$ : 1-year results in people wwith T2DM using basal insulin with OADs, 2nd ed. Am Diabetes Assoc. 2014; abstract 93-LB

9. Fritsche A, Schweitzer MA, Häring HU. Glimepiride combined with morning insulin glargine, bedtime neutral protamine hagedorn insulin, or bedtime insulin glargine in patients with type 2 diabetes. A randomized, controlled trial. Ann Intern Med. 2003;138(12):952-9.

10. Ashwell SG, Gebbie J, Home PD. Twice-daily compared with once-daily insulin glargine in people with type 1 diabetes using meal-time insulin aspart. Diabetes Med. 2006;23(8):879-86.

11. Riddle MC, Rosenstock J, Gerich J. The treat-to-target trial: randomized addition of glargine or human NPH insulin to oral therapy of type 2 diabetic patients. Diabetes Care. 2003;26(11):3080-6.

12. Hassan K, Rodriguez LM, Johnson SE, Tadlock S, Heptulla RA. A randomized, controlled trial comparing twice-a-day insulin glargine mixed with rapid-acting insulin analogs versus standard neutral protamine Hagedorn (NPH) therapy in newly diagnosed type 1 diabetes. Pediatrics. 2008;121(3):e466-72.

13. King AB. Once-daily insulin detemir is comparable to once-daily insulin glargine in providing glycaemic control over $24 \mathrm{~h}$ in patients with type 2 diabetes: a double-blind, randomized, crossover study. Diabetes Obes Metab. 2009;11(1):69-71.

14. Kolendorf K, Ross GP, Pavlic-Renar I, Perriello G, Philotheou A, Jendle J, et al. Insulin detemir lowers the risk of hypoglycaemia and provides more consistent plasma glucose levels compared with NPH insulin in type 1 diabetes. Diabet Med. 2006;23(7):729-35.

15. Russell-Jones D, Simpson R, Hylleberg B, Draeger E, Bolinder J. Effects of QD insulin detemir or neutral protamine Hagedorn on blood glucose control in patients with type I diabetes mellitus using a basal-bolus regimen. Clin Ther. 2004;26(5):724-36.

16. Home P, Bartley P, Russell-Jones D, Hanaire-Broutin $\mathrm{H}$, Heeg JE, Abrams $\mathrm{P}$, et al. Insulin detemir offers improved glycemic control compared with NPH insulin in people with type 1 diabetes: a randomized clinical trial. Diabetes Care. 2004;27(5):1081-7.

17. Onishi Y, Ono Y, Rabøl R, Endahl L, Nakamura S. Superior glycaemic control with once-daily insulin degludec/insulin aspart versus insulin glargine in Japanese adults with type 2 diabetes inadequately controlled with oral drugs: a randomized, controlled phase 3 trial. Diabetes Obes Metab. 2013;15(9):826-32.

18. Fulcher G, Christiansen JS, Bantwal G, Polaszewska-Muszynska M, Mersebach H, Andersen TH. Comparison of insulin degludec/ insulin aspart and biphasic insulin aspart 30 in uncontrolled, insulin-treated type 2 diabetes: a phase 3a, randomized, treat-to-target trial. Diabetes Care. 2014;37(8):2084-90.

19. Hirsch IB, Bode B, Courreges JP, Dykiel P, Franek E, Hermansen K, King A. Insulin degludec/insulin aspart administered once daily at any meal, with insulin aspart at other meals versus a standard basal-bolus regimen in patients with type 1 diabetes: a 26-week, phase 3, randomized, open-label, treat-to-target trial. al. Diabetes Care. 2012;35(11):2174-81.

20. Kaneko S, Chow F, Choi DS, Taneda S, Hirao K, Park $\mathrm{Y}$, Andersen TH. Insulin degludec/insulin aspart versus biphasic insulin aspart 30 in Asian patients with type 2 diabetes inadequately controlled on basal or pre-/self-mixed insulin: a 26-week, randomised, treat-to-target trial. Diabetes Res Clin Pract. 2015;107(1):139-47.

21. Yang W, Xu X, Liu X, Yang G, Seino Y, Andersen H, Jinnouchi H. Treat-to-target comparison between once daily biphasic insulin aspart 30 and insulin glargine in Chinese and Japanese insulin-naïve subjects with type 2 diabetes. Curr Med Res Opin. 2013;29(12):1599-608.

22. Raskin P, Allen E, Hollander P, Lewin A, Gabbay RA, $\mathrm{Hu}$ P. Initiating insulin therapy in type 2 diabetes: a comparison of biphasic and basal insulin analogs. Diabetes Care. 2005;28(2):260-5. 
23. Garber AJ, Wahlen J, Wahl T, Bressler P, Braceras R, Allen E, Jain R. Attainment of glycaemic goals in type 2 diabetes with once-, twice-, or thrice-daily dosing with biphasic insulin aspart 70/30 (The 1-2-3 Study). Diabetes Obes Metab. 2006;8(1):58-66.

24. Kalra S, Plata-Que T, Kumar D, Mumtaz M, Søndergaard F, Kozlovski P, et al. Initiation with once-daily BIAsp 30 results in superior outcome compared to insulin glargine in Asians with type 2 diabetes inadequately controlled by oral anti-diabetic drugs. Diabetes Res Clin Pract. 2010;88(3):282-8.

25. Yang W, Ji Q, Zhu D, Yang J, Chen L, Liu Z, et al. Biphasic insulin aspart 30 three times daily is more effective than a twice-daily regimen, without increasing hypoglycemia, in Chinese subjects with type 2 diabetes inadequately controlled on oral antidiabetes drugs. Diabetes Care. 2008;31(5):852-6.

26. Ligthelm RJ, Mouritzen $U$, Lynggaard $H$, Landin-Olsson M, Fox C, le Devehat C, et al. Biphasic insulin aspart given thrice daily is as efficacious as a basal-bolus insulin regimen with four daily injections: a randomised open-label parallel group four months comparison in patients with type 2 diabetes. Exp Clin Endocrinol Diabetes. 2006;114(9):511-9.

27. Koivisto VA, Tuominen JA, Ebeling P. Lispro Mix25 insulin as premeal therapy in type 2 diabetic patients. Diabetes Care. 1999;22(3):459-62.

28. Roach, Koledova E, Metcalfe S, Hultman C, Milicevic Z. Glycemic control with Humalog Mix25 in type 2 diabetes inadequately controlled with glyburide. Clin Ther. 2001;23(10):1732-44.

29. Jia W, Xiao X, Ji Q, Ahn KJ, Chuang LM, Bao Y. Comparison of thrice-daily premixed insulin (insulin lispro premix) with basal-bolus (insulin glargine once-daily plus thrice-daily prandial insulin lispro) therapy in east Asian patients with type 2 diabetes insufficiently controlled with twice-daily premixed insulin: an open-label, randomised, controlled trial. Lancet Diabetes Endocrinol. 2015;3(4):254-62.

30. Tirgoviste CI, Străchinariu R, Farcaşiu E, Milicevic Z, Teodorescu G. Humalog Mix 25 in patients with type 2 diabetes which do not achieve acceptable glycemic control with oral agents: results from a phase III, randomized, parallel study. Rom J Intern Med. 2003;41(2):153-62.

31. Clements MR, et al. Improved glycaemic control of thrice-daily biphasic insulin aspart compared with twice-daily biphasic human insulin; a randomized, open-label trial in patients with type 1 or type 2 diabetes. Diabetes Obes Metab. 2008;10(3):229-37.
32. Shanmugasundar G, Bhansali A, Walia R, Dutta P, Upreti V. Comparison of thrice daily biphasic human insulin (30/70) versus basal detemir and bolus aspart in patients with poorly controlled type 2 diabetes mellitus-a pilot study. Indian J Med Res. 2012;135:78-83.

33. McNally PG, Dean JD, Morris AD, Wilkinson PD, Compion G, Heller SR. Using continuous glucose monitoring to measure the frequency of low glucose values when using biphasic insulin aspart 30 compared with biphasic human insulin 30: a double-blind crossover study in individuals with type 2 diabetes. Diabetes Care. 2007;30(5):1044-8.

34. Raskin P, Guthrie RA, Leiter L, Riis A, Jovanovic L. Use of insulin aspart, a fast-acting insulin analog, as the mealtime insulin in the management of patients with type 1 diabetes. Diabetes Care. 2000;23(5):583-8.

35. Rossetti P, Pampanelli S, Fanelli C, Porcellati F, Costa E, Torlone E, Scionti L, Bolli GB. Intensive replacement of basal insulin in patients with type 1 diabetes given rapid-acting insulin analog at mealtime: a 3-month comparison between administration of NPH insulin four times daily and glargine insulin at dinner or bedtime. Diabetes Care. 2003;26(5):1490-6.

36. Yki-Jarvinen $\mathrm{H}$, Dressler A, Ziemen M. Less nocturnal hypoglycemia and better post-dinner glucose control with bedtime insulin glargine compared with bedtime NPH insulin during insulin combination therapy in type 2 diabetes. HOE 901/3002 Study Group. Diabetes Care. 2000;23(8):1130-6.

37. Rostami P, Setoudeh A, Rabbani A, Najmi Varzaneh F, Rezaeial N. Efficacy of insulin glargine and aspart, compared to NPH and regular insulin in children with type 1 diabetes mellitus. Iran J Pediatr. 2014;4(2):173-8.

38. Home PD, Hallgren P, Usadel KH, Sane T, Faber J, Grill V, et al. Pre-meal insulin aspart compared with pre-meal soluble human insulin in type 1 diabetes. Diabetes Res Clin Pract. 2006;71(2):131-9.

39. Danne T, Råstam J, Odendahl R, Näke A, Schimmel U, Szczepanski R, et al. Parental preference of prandial insulin aspart compared with preprandial human insulin in a basal-bolus scheme with NPH insulin in a 12-wk crossover study of preschool children with type 1 diabetes. Pediatric Diabetes. 2007;8(5):278-85.

40. Mathieu C, Rodbard HW, Cariou B, Handelsman Y, Philis-Tsimikas A, Ocampo Francisco AM. A comparison of adding liraglutide versus a single daily dose of insulin aspart to insulin degludec in subjects with type 2 diabetes (BEGIN: VICTOZA 
ADD-ON). Diabetes Obes Metab. 2014;16(7): 636-44.

41. Garber AJ, King AB, Del Prato S, Sreenan S, Balci MK, Muñoz-Torres M. Insulin degludec, an ultra-long acting basal insulin, versus insulin glargine in basal-bolus treatment with mealtime insulin aspart in type 2 diabetes (BEGIN Basal-Bolus Type 2): a phase 3, randomised, open-label, treat-to-target non-inferiority trial. Lancet. 2012;379(9825):1498-507.

42. Bernard JB, Munoz C, Harper J, Muriello M, Rico E, Baldwin D. Treatment of inpatient hyperglycemia beginning in the emergency department: a randomized trial using insulins aspart and detemir compared with usual care. J Hosp Med. 2011;6(5): 279-84.

43. Rodbard HW, Visco VE, Andersen H, Hiort LC, Shu DH. Treatment intensification with stepwise addition of prandial insulin aspart boluses compared with full basal-bolus therapy (FullSTEP Study): a randomised, treat-to-target clinical trial. Lancet Diabetes Endocrinol. 2014;2(1):30-7.

44. Umpierrez GE, Hor T, Smiley D, Temponi A, Umpierrez D, Ceron $\mathrm{M}$, et al. Comparison of inpatient insulin regimens with detemir plus aspart versus neutral protamine Hagedorn plus regular in medical patients with type 2 diabetes. J Clin Endocrinol Metab. 2009;94(2):564-9.

45. Tinahones FJ, Gross JL, Onaca A, Cleall S, Rodríguez A. Insulin lispro low mixture twice daily versus basal insulin glargine once daily and prandial insulin lispro once daily in patients with type 2 diabetes requiring insulin intensification: a randomized phase IV trial. Diabetes Obes Metab. 2014;16(10):963-70.

46. Bretzel R, Nuber U, Landgraf W, Owens DR, Bradley C, Linn T. Once-daily basal insulin glargine versus thrice-daily prandial insulin lispro in people with type 2 diabetes on oral hypoglycaemic agents (APOLLO): an open randomised controlled trial. Lancet. 2008;371(9618):1073-84.

47. Bowering K, Reed VA, Felicio JS, Landry J, Ji L, Oliveira J. A study comparing insulin lispro mix 25 with glargine plus lispro therapy in patients with type 2 diabetes who have inadequate glycaemic control on oral anti-hyperglycaemic medication: results of the PARADIGM study. Diabet Med. 2012;29(9):e263-72.
48. Riddle MC, Vlajnic A, Zhou R, Rosenstock J. Baseline HbA1c predicts attainment of $7.0 \%$ HbA1c target with structured titration of insulin glargine in type 2 diabetes: a patient-level analysis of 12 studies. Diabetes Obes Metab. 2014;15(9):819-25.

49. Ito H, Abe M, Antoku S, Omoto T, Shinozaki M, Nishio S, et al. Effects of switching from prandial premixed insulin therapy to basal plus two times bolus insulin therapy on glycemic control and quality of life in patients with type 2 diabetes mellitus. Drug Des Devel Ther. 2014;23(8):391-6.

50. Urata $\mathrm{H}$, et al. Advantage of insulin glulisine over regular insulin in patients with type 2 diabetes and severe renal insufficiency. J Ren Nutr. 2015;25(2): 129-34.

51. Choe EY, Lee YH, Lee BW, Kang ES, Cha BS, Lee HC. Glycemic effects of once-a-day rapid-acting insulin analogue addition on a basal insulin analogue in Korean subjects with poorly controlled type 2 diabetes mellitus. Diabetes Metab J. 2012;36(3):230-6.

52. Fritsche A, Larbig M, Owens D, Häring HU, GINGER study group. Comparison between a basal-bolus and a premixed insulin regimen in individuals with type 2 diabetes-results of the GINGER study. Diabetes Obes Metab. 2010;12(2):115-23.

53. Gough SCL, Bode B, Woo V, et al. Efficacy and safety of a fixed-ratio combination of insulin degludec and liraglutide (IDegLira) compared with its components given alone: results of a phase 3 , open-label, randomised, 26-week, treat-to-target trial in insulin-naïve patients with type 2 diabetes. Lancet Diabetes Endocrinol. 2014;2:885-93.

54. Buse JB, Vilsboll T, Thurman J, et al. Contribution of liraglutide in the fixed-ratio combination of insulin degludec and liraglutide (IDegLira). Diabetes Care. 2014;37:2926-33.

55. Riddle CM, Forst $\mathrm{T}$, Aronson R, et al. Adding once-daily lixisenatide for type 2 diabetes inadequately controlled with newly initiated and continuously titrated basal insulin glargine: a 24-week, randomized, placebo-controlled study (GetGoal-Duo 1). Diabetes Care. 2013;36:2497-503.

56. Ahren B, Dimas AL, Miossec P, et al. Efficacy and safety of lixisenatide once-daily morning or evening injections in type 2 diabetes inadequately controlled on metformin (GetGoal-M). Diabetes Care. 2013;36:2543-50. 